\title{
Terrorism and Jihad in Islamic Perspective
}

\author{
Doly Andhika Putra ${ }^{*}$, Ni Made Sumaryani² \\ ${ }^{1}$ Department Defense Management, Indonesia Defense University, Indonesia \\ 2Department Asymmetric Warfare, Indonesia Defense University, Indonesia \\ *Corresponding Author E-mail: doly17andhika@gmail.com
}

\begin{abstract}
Being the most discussed issue in various parts of the world (including Indonesia), Terrorism is considered contrary to humanitarian understanding, which causes losses, both economically, politically, and psychologically. The issue of Terrorism has recently become a hot topic of public discussion. The reason is that terrorists massively use the word Jihad as a justification for their actions. This article uses a descriptive qualitative approach as the primary writing approach. In-depth search for various literature appropriate to the discussion of Jihad and Terrorism from an Islamic point of view. Religion is one of the motivations for a person to join a terror group. Religion is one reason that encourages the emergence of Terrorism due to the oppression that occurs in religion in a specific country. Call it Syria, which is famous for its wars; from there, terrorist groups spread to Indonesia by igniting the spirit of Jihad as citizens who share the same religion share the same fate. After a deeper investigation, the Jihad often campaigned by terror groups is not like Jihad from an Islamic point of view.
\end{abstract}

Keywords: Terrorism, Jihad, Islam

\section{INTRODUCTION}

Terrorism is an issue that is widely discussed in various parts of the world, including Indonesia. Terrorism is considered contrary to the understanding of humanity that causes harm, both economically, politically, and psychologically. The issue of Terrorism has recently become a hot topic of public discussion. The form of acts of Terrorism that appear is very surprising and far from acts of Terrorism in general. The most shocking story begins with the suicide bombing carried out by one family in three churches (GKI Diponegoro, Santa Maria Church, and Pentecostal Church) in Surabaya in May 2018 which became the public spotlight. This family is suspected to be a network of Jamaah Ansharud Daulah (JAD) (Surpi et al., 2019). In 2021, Indonesia was again shocked by the explosion of a suicide bombing in front of the Makassar Cathedral Church on Sunday, March 23, 2021, which was suspected to be a married couple who had only been married a few months. (Abdullah, 2021). Not enough with the action in Makassar, on Wednesday, March 31, 2021, another terrorist attack took place at the Indonesian National Police Headquarters (Police Headquarters). A woman carried out the perpetrator of the attack on the National Police Headquarters with the initials ZA. National Police Chief General Listyo Sigit Prabowo stated that the character of terror carried out by the perpetrator was a lone wolf or terror acts carried out individually or alone. In addition, ZA is considered to have been exposed to the ideology of the Islamic State of Iraq Syria (ISIS) seen from his social media accounts (Thohirin, 2021).

The two acts of Terrorism that co-occurred as mentioned above refer to the same goal, namely Jihad as the highest practice towards Heaven as written in the will left by the perpetrator for his family. The rise of acts of Terrorism in the last few decades has created a negative stigma among Indonesian people. In addition to terrorist actors who claim to be Muslim, they also claim that their actions are a manifestation of Jihad fisabilillah, which is a struggle against injustice and oppression experienced by Muslims.

*Copyright (c) 2020 Doly Andhika and Ni Made Sumaryani

This work is licensed under a Creative Commons Attribution-ShareAlike 4.0 International License.

Received: May 1 2021; Revised: Juny 19 2021; Accepted: Juny 262021 
IJIK, Vol. 11 No. 2: 78-89

Terrorism and Jihad in Islamic Perspective

Doly Andhika, Ni Made Sumaryani

Several previous studies on Terrorism and Jihad, such as the research conducted by Majid (2014), aimed to examine Terrorism in Muslim groups, which include the nature of Terrorism, Terrorism from an Islamic perspective, and Muslim groups that are considered terrorists, Asmara (2016) conducted a study to examine the apparent difference between Jihad and terrorists, where Jihad is considered the root cause of Terrorism due to misunderstandings about religion, and Naharong (2013) conducted research intending to elaborate on religious/holy Terrorism or new Terrorism according to several scientists. To cover some of the shortcomings in previous research, this study will discuss more deeply one's motivation to become a terrorist, the Islamic view of Jihad, and the popularity of Jihad as a justification for acts of Terrorism.

Currently, Jihad is a sensitive issue that is often associated with Terrorism. For people who do not understand Islam's teachings, it will be easy to confuse the terminology between the meaning of Jihad and acts of Terrorism just by looking at some militant groups who use Jihad as a protector and justification for their activities.

\section{RESEARCH METHOD}

This article is the result of research using a descriptive qualitative approach model as the main writing approach. Descriptive qualitative research is a research method that is usually used to examine objective natural conditions where the researcher acts as a key instrument (Sugiyono, 2008). The data used in this research is secondary data in the form of a literature study. The literature study was carried out by searching for various literature that matched the discussion on Jihad and Terrorism from an Islamic point of view. This search process begins with an online search for journals in various journal databases and websites through Google and Google Scholar search engines. In addition, offline searches of books, printed journals, and policy documents were also carried out. This search focused on literature published in 2000-2021. The research results are then reduced and taken that are in line with the research topic as reference material in this writing.

\section{RESULTS AND DISCUSSION}

\section{Result}

\section{Motivation to Become a Terrorist}

Terrorism is synonymous with the word 'terror,' which means activities that create fear, horror, or cruelty by a person or group. The absence of a uniform definition according to international law regarding Terrorism causes different definitions of each country based on its national law to regulate, prevent and combat Terrorism. Based on Article 1 Paragraph (2) of Law Number 5 of 2018, Terrorism is defined as an act that uses violence or threats of violence that create an atmosphere of terror or widespread fear, which can cause mass casualties and cause damage or destruction to objects. Strategic vital, environmental, public facilities, or international facilities with ideological, political, or security disturbance motives. Yosua Praditya stated that Terrorism could be described through 3 keys, namely (1) having committed acts of violence, (2) having political aims, and (3) having the intended target audience (Praditya, 2016).

Terrorism as a social phenomenon has developed from time to time. The terrorism movement in Indonesia, with its increasingly widespread and varied objectives, strategies, motivations, targets, and methods, makes it a crime against human peace and security (Junaid, 2013). The acts of Terrorism that occurred in Indonesia from 1981-2021, namely: 
1. The hijacking of Garuda Indonesia flight 206 on March 28, 1981;

2. The Borobudur Temple Bombings on January 21, 1985;

3. The bombing of the Philippine Embassy on August 1, 2000, Bombing of the Malaysian Embassy on August 27, 2000, Bombing of the Jakarta Stock Exchange on September 13, 2000, Christmas Eve Bombing on December 24, 2000, in several cities in Indonesia;

4. Santa Anna Church and HKBP Bombings on July 22, 2001, Plaza Atrium Senen Jakarta Bombings on September 23, 2001, Bombings of KFC Restaurant in Makassar on October 12, 2001, Bombing of Australian Schools in Jakarta on November 6, 2001;

5. New Year's Bombing on January 1, 2002, Bali Bombing I on October 12, 2002, Bombing of McDonald's Restaurant in Makassar on December 5, 2002;

6. The bombing of the Police Headquarters Complex in Jakarta on February 3, 2003, Bombing of Soekarno-Hatta Airport on April 27, 2003, Bombing of JW Marriott on August 5, 2003;

7. The Palopo Bombing on January 10, 2004, the Bombing of the Australian Embassy on September 9, 2004, the Bombing of the Immanuel Church in Palu on December 12, 2004;

8. Two bombs exploded in Ambon on March 21, 2005, Tentena Bomb on May 28, 2005, Pamulang Bomb in Tangerang on June 8, 2005, Bali II Bombing on October 1, 2005, Palu Market Bomb on December 31, 2005;

9. The Jakarta Bombing on July 17, 2009;

10. Shooting of civilians in Aceh in January 2010, CIMB Niaga Bank Robbery in September 2010;

11. Cirebon Bombing on April 15, 2011, Gading Serpong Bombing on April 22, 2011, Solo Bombing on September 25, 2011;

12. Solo Bombing on August 19, 2012;

13. Poso Police Bombing on June 9, 2013;

14. Bombing and shooting at each other in Jakarta on January 14, 2016, Suicide Bombing at the Surakarta City Police Headquarters on July 5, 2016, Suicide Bombing at the St. Joseph Catholic Church, Medan City on August 28, 2016, Molotov cocktails in front of the Ecumenical Church Samarinda City on November 13, 2016, Molotov cocktails at Vihara Budi Dharma Singkawang City on November 14, 2016;

15. Pot Bomb in Kampung Melayu on 24 May 2017, Pot Bomb at Pandawa Park Cicendo Bandung on 27 February 2017;

16. Hostage of members of Brimob and Densus 88 by 156 Terrorism Convicts on May 8, 2018, Surabaya Bombing on 13-14 May 2018, JAD Attackers to Riau Police Headquarters on May 16, 2018;

17. The Sibolga Bombing on March 12, 2019; and

18. The Makassar Bombing on March 28, 2021, and the attack on the National Police Headquarters on March 31, 2021. 
IJIK, Vol. 11 No. 2: 78-89

Terrorism and Jihad in Islamic Perspective

Doly Andhika, Ni Made Sumaryani
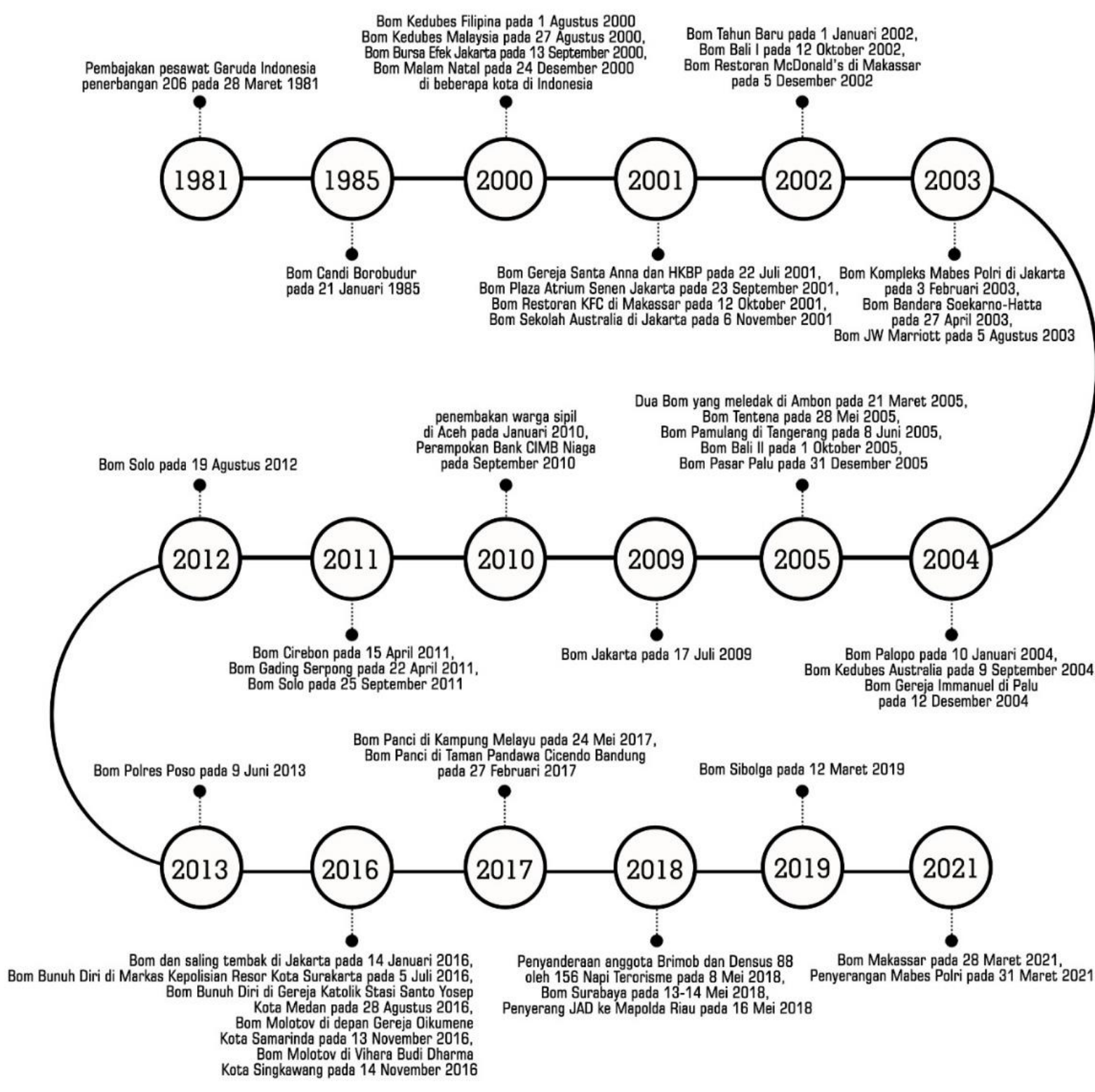

Figure 1. Acts of Terrorism in Indonesia 1981-2021

Source: Processed by researchers (2021)

Based on figure 1, the terrorism events from 1981-2021, the suicide bombers committed by women and children only occurred in May 2018 and March 2019. The appearance of women and children as terrorists certainly triggers a polemic, so it is necessary to know what motivates someone to become a terrorist. Salahuddin Wahid stated several reasons that motivate someone to become a terrorist, including religion, ideology, fighting for independence, freeing oneself from injustice, and certain interests (Mareta, 2018; Qotadah \& Achmad, 2021).

The Head of Sub-Directorate for Community Development of the Directorate of Deradicalization of BNPT, Solihuddin Nasution, stated that the root of the problem of radicalism and Terrorism was triggered by several factors, namely revenge, hatred, injustice, social inequality, poverty, discriminatory policies, 
IJIK, Vol. 11 No. 2: 78-89

Terrorism and Jihad in Islamic Perspective

Doly Andhika, Ni Made Sumaryani

ideology/understanding, and misunderstanding of religious teachings (Nasution, 2018). Some of the dominant motivations that encourage someone to become a terrorist in Indonesia (Surpi et al., 2019), namely:

\section{Religious Reason}

Almost all of the terrorist incidents in Indonesia in Islam, such as Jamaah Islamiah, Katibah Nusantara, ISIS, and so on, have earned Indonesia the title of "terrorism nest" in ASEAN (Liputan6, 2012). Religion is one reason that encourages the emergence of Terrorism due to the oppression that occurs in religion in a certain country. Call it Syria, which is famous for its war. From there, terrorist groups spread to Indonesia by igniting the spirit of Jihad as citizens who share the same religion, share the same fate, and share the same fate. So that the countries with the largest Muslim population sympathize and support the movement of their brothers and sisters in Syria. It is the same with the reasons behind the bombings that occurred in Bali and several churches on Christmas Eve, which were carried out as an effort to retaliate against the savagery of the Zionist Israel and America against Muslims both in Palestine, Afghanistan, Somalia, Kashmir, Chechnya and so on (M. Z. Mubarak, 2015).

\section{Ideological Reason}

Ideology determines how terrorist members see the world around them and identify enemies by providing explanations and justifications for why certain people or institutions should be attacked (Naharong, 2015). Khadduri said that in Islamic discourse, many people associate the ideology of Terrorism with the doctrine of Jihad, which in Christianity is equated with a crusade (Z. Mubarak, 2012). Terrorism in Indonesia tends to adhere to the caliphate ideology and overrides the Pancasila ideology as the state ideology.

\section{Freeing Yourself from Injustice}

Freeing oneself from injustice is a significant thing that motivates a person to become a terrorist. In this case, all parties feel that they are victims, so it is necessary to carry out movements to demand justice from the government. This condition makes a person anesthetized by the proclamations of Jihad on social media, especially those that are against the government. In other words, the people who are interested in becoming terrorists are those who are not in line with the government.

\section{Certain interests}

Elements of certain interests that motivate someone to become a terrorist can be in the form of political interests against certain governments or revenge from the descendants of terrorists where the spirit of Jihad has been passed down in them, which triggers more violent acts of Terrorism. In this case, the motivation of the descendants of terrorists is the spirit of Jihad and revenge because their parents were killed on the grounds of sentencing the perpetrators of Terrorism.

\section{Discussion}

The problem of transmitting radicalism which refers to acts of Terrorism, is caused by injustice and feels the most victimized, so it is necessary to find people who share the same fate as themselves to fight the government. Weak conditions like this are very likely to accept radical doctrines obtained through the mass media (Lestari, 2021). So that someone feels he has found a friend who shares the same fate as him 
so that he joins to find his identity. In taking the path of Terrorism, a person will experience several phases, namely sympathizers, supporters, collaborators, recruits, cadres, and leaders.

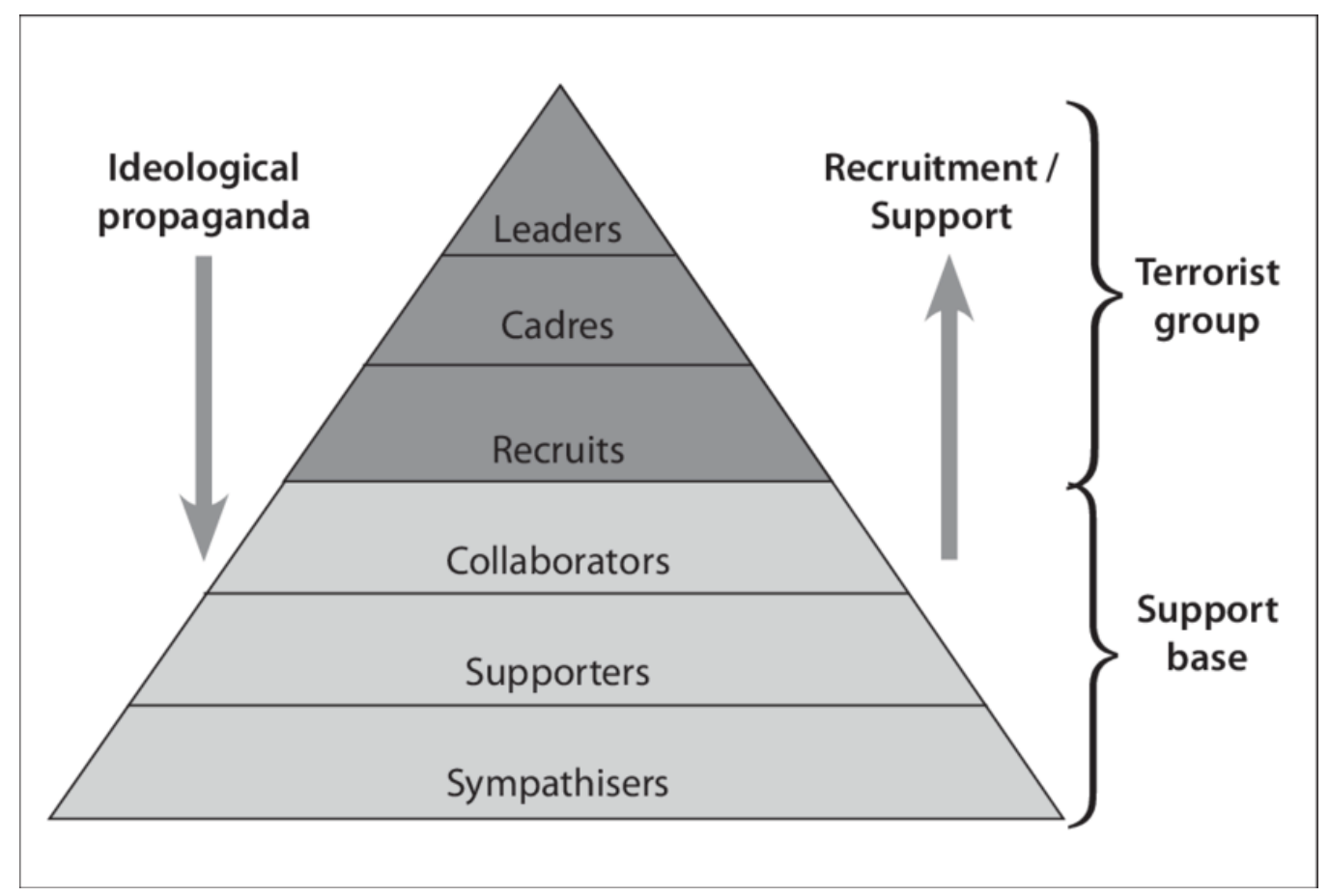

Figure 2. Terrorism Phase

Source: (Hassan, 2011)

Figure 2 shows the phase, sympathizers, supporters, and collaborators are referred to as the support base for the occurrence of acts of Terrorism. Meanwhile, recruits, cadres, and leaders are terrorist groups where the anti-ideological doctrines of Pancasila have been fixed in their minds. They are the ones who work in ideological propaganda to influence others to join.

\section{Jihad in Islam}

Understanding Jihad requires a thorough and deep meaning. Jihad has a very broad meaning. Currently, the concept of Jihad still raises differences of opinion. In the Qur'an, there are words of war and suggestions for doing so, but we must first examine what is meant by Jihad in Islamic teachings and what reasons allow a Muslim to fight.

In the Big Indonesian Dictionary (KBBI), Jihad has meanings, namely: Efforts with efforts to achieve goodness, serious efforts to defend Islam at the expense of property, soul, and body, and holy war to defend Islam against infidelity. (Tim Redaksi Kamus Besar Bahasa Indonesia, 2008).

The Book of Al-Fiqh Al-Muyassar states that Jihad is to exert all abilities and strength in fighting the disbelievers and against them. In Lisan al-'Arab, Ibnu Mandzur explains that Jihad is fighting the enemy by devoting all abilities and energy to words, deeds, or everything capable. According to Sami'un Jazuli, quoting Al-Kasami suggests Jihad as an effort to mobilize all potential and strength to fight in the way of Allah with wealth, property, and others (Jazuli, 2005). Meanwhile, according to Hasan al-Banna, Jihad, as quoted by Yusuf al-Qardhawi, is a Muslim obligation that continues until the Day of Judgment (AlQardhawi, 1989). 
According to Quraish Shihab, who quoted Ibn Faris' opinion in the book Mu'jam al-Maqayis fi alLughah, "all words consisting of the letters Jim-ha'-dal, contain the meaning of difficulty or difficulty and are similar to it" (Shihab, 1996).

The commandment regarding Jihad is mentioned in the Quran 41 times. The orders regarding Jihad were partly descended in the Meccan period, and others came down in the Medina period.

Verses about Jihad in the Mecca period are found in Q.S An-Nahl 38, Q.S An-Nahl:110, Q.S AlFurqan:52, Q.S Al-Ankabut:6, Q.S Al-Ankabut:8, Q.S Al-Ankabut:69, Q.S Lukman:15, dan Q.S Al-An'am:109. While the verses regarding Jihad in the Medina period are found in Q.S Al-Baqarah 218, Q.S Al-Baqarah 273, Q.S Ali Imran:142, Q.S An-Nisa:95, Q.S Al-Ma'idah:35, Q.S Al-Maidah 53, Q.S Al-Ma'idah:54, Q.S Al-'Anfal:72, Q.S Al-'Anfal:74, Q.SAt-Taubah:16, Q.SAt-Taubah:19, Q.SAt-Taubah:20, Q.SAt-Taubah:24, Q.SAt-Taubah:41, Q.S At-Taubah:44, Q.S At-Taubah:73, Q.S At-Taubah:79, Q.S At-Taubah:81, Q.S At-Taubah:86, Q.S AtTaubah:87, Q.S At-Taubah:88, Q.S At-Taubah:91, Q.S Al-Haj:78, Q.S Muhammad:31, Q.SAl-Hujurat:15, Q.S AlMumtahanah:1, Q.S Ash-shaf:11, Q.S Al-Tahrim:9, Q.S An-Nur:53, Q.S Al-Hajj:78, and Q.S, Fathir:42

There are differences between the Jihad verses in the Meccan period with the Jihad verses in the Medina period. Among the characteristics of the Makkah verse that is by the theme of Jihad lies in the style of language that is strong, effective, varied, and reveals the basic principles of Islamic teachings (Darwazah, 2000). The Jihad verses of the Meccan period generally call for preaching and spreading Islam among the Quraysh tribal community so that the teachings of Islam can be well received and being patient with actions that hurt Muslims at that time. In the Mecca period, the invitation to Jihad did not mention the issue of war at all.

Meanwhile, the verses of the Medina period call on the believers to face the enemy aggressively and oblige them to fight the unbelievers according to the conditions of the Muslims at that time. At this time, Muslims have been formed in an organized order so that a strategy is needed to defend themselves to realize a safe and peaceful Islamic society. For a Muslim, war is the last resort that can be done in upholding his religion after da'wah's path. Because war has a very high risk, bloodshed from the Muslims themselves and the opposing side (Fattah, 2016).

Regarding the law of Jihad, Fiqh scholars agree that the law of Jihad is obligatory. Still, there are differences of opinion regarding the law of Jihad between Fardhu 'Ain and Fardhu Kifayah. The majority of scholars hold the opinion that the law of Jihad is Fardhu Kifayah. What is meant by Fardhu Kifayah Jihad is that if some or a group of people have performed the obligation of Jihad, then the obligation of Jihad for others will fall. The legal basis that stipulates the law of Jihad is contained in the words of Allah Q.S AlBaqarah: 216:

"It is obligatory for you to fight, even though it is not pleasant for you. It may be that you dislike something when it is good for you, and it may be that you like something, but it is not good for you. Allah is All-Knowing, and you do not know" (Indonesia, 2004).

Jihad can be done in various ways, such as with the heart, words, and deeds. Islam is a religion that upholds compassion for fellow human beings. Jihad is also not merely an invitation to war but also a call for monotheism and upholding Allah's commands.

The order of Jihad aims to protect and defend oneself from the threats and challenges of the infidels in spreading the da'wah of Islam. In the Qur'an, there are words of war and suggestions for war, but we must first examine the meaning of war which is prescribed in Islam. In the Qur'an, Allah only allowed Muslims to fight as an act of defense to defend themselves and respond to persecution and attacks by infidels (Asmara, 2016). This is contained in Q.S Al-Hajj verse 39: 
IJIK, Vol. 11 No. 2: 78-89

Terrorism and Jihad in Islamic Perspective

Doly Andhika, Ni Made Sumaryani

"It has been permitted (to fight) for those who are being fought, because indeed they have been wronged, and indeed Allah, the Almighty, really helps them." (Indonesia, 2004).

In addition, the command regarding Jihad in the form of war is also contained in Q.S Al Baqarah verse 190:

"And fight in the way of Allah those who fight you, (but) do not transgress, because Allah does not like those who transgress" (Indonesia, 2004).

Yusuf Qardhawi divides Jihad into three levels. First, Jihad against visible enemies. Second, Jihad faces Satan's temptations, and Third, Jihad against lust (Qardhawi, 2010). According to Bahrun Abu Bakr (1986) in Al-Maraghi, there are four scopes of Jihad: (1) War in the context of defending religion and its adherents to elevate the word of God, (2) Combating lust, (3) Jihad with property for good deeds. And (4) Jihad against falsehood and defending the truth (Fattah, 2016).

Meanwhile, Ibn Taimiyah in the Book of Zaad Al Ma'ad, Jihad is divided into four parts, namely: (1) the lightest Jihad, is fighting on the battlefield against enemies who want to destroy Allah's religion; (2) Jihad that is greater than that is Jihad against hypocrites, namely those whose mouths are against the enemy but in action they unite with the enemy; (3) An even greater jihad, against the devil and demons who always deceive humans, and the fourth (4) The most terrible Jihad is against oneself, which is against the bad will that is in ourselves (Saidurrahman, 2012).

Muqatil Ibn Sulaiman introduces three meanings of Jihad. First, Jihad is a struggle with words, speech, and thoughts (Jihad bi al-Qaul). Second, Jihad by fighting and using weapons (al-qital bi al silah). Third, Jihad by working and trying (Jihad bi al 'Amal) (Sulaiman, 2005). Meanwhile, according to Salih Ibn Abdullah al-Fauzan, there are five goals in Jihad, namely: Jihad against lust, Jihad against demons, Jihad against those who commit immorality, Jihad against hypocrites, and Jihad against infidels (Salendra, 2009).

\section{Jihad Trend in Terrorism}

In the last few decades, news about acts of violence (terrorism) occupies the top news that grabs the attention of the Indonesian people. The violence that takes the life of a person or group of people occurs in the form of attacks or in the form of suicide bombings. Violence, conflict, bombings seem to be used as reasons to carry out Jihad under the pretext of upholding the religion of Allah.

In the history of the movement in Indonesia, the ideology of Jihad emerged in tandem with the efforts to stem colonialism and imperialism by the West. The arrival of the West to the archipelago in the 16 th century with the mission of gold, glory, and gospel immediately published feelings of hostility among the Indonesian people. History records that the first Sabil War in the archipelago occurred at the beginning of the 16th century AD when the Portuguese Christian Kingdom, in 1511, carried out military aggression against the Islamic Kingdom of Malacca, which Sultan Mahmud Shah then ruled I (1488-1511 AD). The Javanese War led by Prince Diponegoro and Kyai Mojo (1825-1830) carried the concept of Jihad. Likewise with the Padri War (1821-1837) led by Imam Bonjol and the Lampung war (1832-1833) led by Imba Koesoema. The Sufi movement of the Tarekat Qadiriyah Naqsabandiyah in 1888 in Banten led by Haji Wasjid resulted from the anger of Muslim farmers who experienced decades of oppression and forced cultivation. The Aceh War, which occurred throughout 1873 until the early 20 th century against the Dutch, was one of the wars that carried the longest Jihad concept in the Indonesian struggle.

Jihad in the sense of war re-emerged in the 20th century after Indonesia declared itself an independent nation to maintain independence from the Dutch who tried to re-colonize. In the battle of 
November 10, 1945, Muslims from various components, such as Muhammadiyah and NU, united in the Sabilillah and Hezbollah armies led by kyai against the invaders to the last drop of blood (Darajat, 2016).

From the Bali Bombings on October 12,2002, and October 1, 2005, to the bombing of the cathedral in Makassar in 2021, the term Jihad has re-emerged, so it is often quoted in various media to give context to the emergence of resistance movements carried out by some religious groups against religious groups. Other. The terrorists who were caught claimed that their actions were Jihad fi Sabililah (Jihad in the way of Allah), and when they died, they hoped for martyrdom as the highest ideal.

For some Muslims, acts of violence, clashes, bombings, and the disappearance of other people's lives are used as a justification under the pretext of Jihad to uphold the religion of Islam. This causes a negative stigma that Islam is a religion that legalizes murder in religious life.

In general, acts of Terrorism in Muslim groups are carried out by Islamic fundamentalist groups. For Westerners, the term Islamic Fundamentalism is often exchanged with other terms, such as Radical Islam or Islamic Extremism. There are also other terms used, such as integrity, revivalism, or Islamism. The term is used to indicate the symptoms of an Islamic revival followed by militancy and fanaticism, which is sometimes very extreme.

For this extremist group, the first requirement in achieving its goal is to overthrow the rulers of a country (national) or several countries (regional), take over power, and then establish an Islamic state (Majid, 2014). Who is the main target of this terror attack? The targets of this movement are foreigners and followers of religions other than Islam. These terrorists often argue that atrocities against Muslims in other parts of the world can be avenged against foreigners or religious people other than Islam in Indonesia. Therefore, the target of a bomb attack is a place that is considered to cause large numbers of victims, from foreigners and followers of other religions besides Islam, such as churches, foreign embassies, to places that are considered immoral.

Any religious teachings never condone acts of Terrorism. Especially when religion is only a shield to carry out terrorism plans so that each recruitment of prospective terrorist members can be based on religious doctrine to make them believe that their actions are a sacred mission that can lead them to the blessing of their God (Handoko, 2019).

The identity of Islam as a religion that brings mercy, safety, and peace, not only for Muslims but also for adherents of other religions and even for the universe, has been tarnished by acts of violence by a group of Muslims who use the label "Jihad" to justify their actions (Efendi, 2013). As a result, not a few parties consider that Terrorism is part of Islamic teachings. They equate Jihad with Terrorism. Jihad and Terrorism are two contradictory things.

Based on the understanding of Jihad and Terrorism that has been stated, it can be concluded that there are differences in understanding between Jihad and acts of Terrorism. Jihad is the struggle of a Muslim in the way of Allah sincerely with full sincerity and hopes for goodness in this world and the hereafter. Jihad is carried out by taking a good way to avoid actions that can harm and injure someone innocent and carried out with a certain code of ethics. According to Hasan Al-Banna, the objectives of Jihad by the Shari'ah are:

1. To reject the hostility towards Islam and the Muslims by the polytheists, infidels, dissidents, and people who hold grudges against Islam;

2. To strengthen the Islamic da'wa so that it can reach those who have the right to know it;

3. To offer Islam to the polytheists, the disbelievers, the wrongdoers, and those who have bad thoughts about Allah;

4. To strengthen the religion and the Shari'ah of Allah; and 
5. To destroy systems contrary to the truth, which oppresses humans and denies human rights in human life (Mahmud, 2001).

Meanwhile, an act of Terrorism is an activity carried out by a person or group of people in the form of violence and brutality, full of threats. It tends to cause innocent victims, both property and life. Terrorism is not procedural according to law and always takes the form of causing harm from various aspects and is vanity because it violates God's prohibition (Mathar, 2009).

What is the view of Islam on acts of Terrorism? In Islam, acts of violence and unreasonable destruction are prohibited. Even Allah condemns those who make mischief on earth. This is by the word of Allah in the Qur'an Surah Al-Maidah verse 33:

"Indeed, the recompense for those who fight against Allah and His Messenger and cause mischief in the earth is only that they are killed or crucified, or their hands and feet are cut off for reciprocity, or they are expelled from the land (where they live). An insult to them in this world, and in the hereafter they will have a great torment" (Indonesia, 2004).

In QS Al Maidah verse 33, it is very clear that Islam forbids humans to make mischief on this earth. Even Allah threatens those who make mischief with the punishment of being killed or crucified or having their hands and feet cut off, or being expelled from the country where the perpetrator lives. At the same time, in the hereafter, they will receive a great punishment. The prohibition to persecute fellow human beings is also described in Q.S Al-A'raf verse 33:

"Say: "My Lord only forbids abominable acts, both visible and hidden, and sinful acts, violating human rights without a just reason, (forbids) associating with Allah with something that Allah has not sent down evidence for and (forbids) making up do against Allah what you do not know" (Indonesia, 2004).

The acts of violence committed by terrorists are not by the teachings of the Islamic religion, which always upholds the value of togetherness and respect between human beings. Islam never teaches its people to be rude to others even though they are non-Muslims. All schools of jurisprudence reject all kinds of killing and destruction by terrorists.

Jihad can include war and spending wealth and all efforts to support Allah's religion, struggle to control lust, and try to maximally carry out Amar Ma'ruf and eradicate evil and injustice (Mutarom, 2016). So it is very unfortunate and concerning if, among the people who confuse the meaning of Jihad and terrorists, it comes from the Muslims themselves, which is ironic. There is no single religious teaching that encourages and encourages its followers to commit violence or acts of terror as Islam has assumed so far (Asmara, 2016).

\section{CONCLUSION}

Jihad is the duty of a believer to defend his religion. Different understandings occur by some Islamic movements, especially radical Islam, by actualizing Jihad as a form of violence. Jihad and Terrorism are significantly different. Jihad is an activity that is carried out in the way of Allah and must be carried out in a good and right way, avoiding harmful actions that can harm and injure a person, property, and the environment, defending individual and community rights, and realizing goodness. Meanwhile, Terrorism is a destructive movement and causes harm from various aspects, creates an atmosphere of terror or fear widely, and causes mass casualties. The act of Terrorism is not by the demands of Islam and is not justified by every religion. 


\section{REFERENCES}

Abdullah, I. (2021, March). Bom Makassar: Dua Terduga Pengebom Suami Istri 'Pengantin Baru', Polisi Temukan 'Lima Bom Aktif' di Bekasi. BBC News Indonesia.

Al-Qardhawi, Y. (1989). Pendidikan Islam dan Madrasah Hasan al-Banna (B. A. Gani \& Z. A. Ahmad (eds.)). Bulan Bintang.

Asmara, M. (2016). Reinterpretasi Makna Jihad Dan Teroris. Al Istinbath: Jurnal Hukum Islam, 1(1), 63-80.

Darajat, Z. (2016). Jihad dinamis: menelusuri konsep dan praktik jihad dalam sejarah Islam. Ijtihad: Jurnal Wacana Hukum Islam Dan Kemanusiaan, 16(1), 1-25.

Darwazah, M. I. (2000). al-Tafsir Wa al-Hadith. Dar al-Gharb al-Islamy.

Efendi, Z. (2013). Jihad dan Terorisme. Al-Hurriyah, 14(2), 131-154.

Fattah, A. (2016). Memaknai Jihad Dalam Al-Qur'an Dan Tinjauan Historis Penggunaan Istilah Jihad. Jurnal Pendidikan Agama Islam, 3(1), 65-88.

Handoko, A. (2019). Analisis Kejahatan Terorisme Berkedok Agama (Analysis of Terrorism Crimes Impersonating Religion). SALAM; Jurnal Sosial \& Budaya Syar-I, 6(2).

Hassan, M. H. (2011). A Decade Combating Radical Ideology: Learning from the Singapore Experience (2001-2011). Researchgate.Net.

Indonesia, D. A. R. (2004). Al Quran dan Terjemahannya. CV Al-Jumanatul Ali.

Jazuli, A. S. (2005). Fiqh al-Qur'an: Kajian atas Tema-Tema Penting dalam al-Quran (1st ed.). Kilau Intan.

Junaid, H. (2013). Pergerakan Kelompok Terorisme Dalam Perspektif Barat dan Islam. Sulesana, 8(2), 118-135.

Lestari, G. (2021). Radikalisme Atas Nama Agama dalam Perspektif Intelektual Muda di Tengah Realitas Multikultural. Khazanah Theologia, 3(3), 181-193.

Liputan6. (2012, September). Dicap Sarang Teroris, Indonesia Harus Punya Jati Diri. Liputan6.Com.

Mahmud, A. A. H. (2001). Fiqh Rekonsiliasi dan Reformasi menurut Hasan Al-Banna, Rukun Jihad, AlIqtisham Cahaya Ummat.

Majid, A. (2014). Terorisme di Lingkungan Kelompok Muslim. Substantia, 16(1), 103-116.

Mareta, J. (2018). Rehabilitasi Dalam Upaya Deradikalisasi Narapidana Terorisme. MasalahMasalah Hukum, 47(4), 338-356.

Mathar, M. S. (2009). Jihad Dan Terorisme Kajian Fikih Kontemporer. Jurnal Hunafa, 6(1), 117-128.

Mubarak, M. Z. (2015). Dari NII ke ISIS: Transformasi Ideologi dan Gerakan dalam Islam Radikal di Indonesia Kontemporer. Episteme, 10(1), 77-98.

Mubarak, Z. (2012). Fenomena Terorisme di Indonesia: Kajian Aspek Teologi, Ideologi dan Gerakan. Salam Jurnal Studi Masyarakat Islam, 15(2), 240-254.

Mutarom, A. (2016). Reorientasi Makna Jihad: Sebuah Tinjauan Historis Terhadap Makna Jihad Dalam Sejarah Umat Islam. Yaqzhan, 2(2), 237-259.

Naharong, A. M. (2015). Terorisme atas Nama Agama. Refleksi, 13(5), 593-622.

Nasution, S. (2018). Bahaya Terorisme dan Radikalisme serta Penanggulangannya.

Praditya, Y. (2016). Optimalizing the synergy of military-police-civillian in Facing Radicalism and Terrorism Threats in Indonesia. Jurnal Pertahanan: Meningkatkan Kebersamaan Melawan Terorisme, 6(1), 31-54.

Qardhawi, Y. (2010). Fiqih Jihad: Sebuah Karya Monumental Trelengkap Tentang Jihad Menurut alQur'an dan Sunnah. Mizan.

Qotadah, H. A., \& Achmad, A. D. (2021). Assessing the Role of Women in Countering Radicalism: an Islamic Perspective. Khazanah Sosial, 3(2), 84-95.

Saidurrahman. (2012). Fiqh Jihad Dan Terorisme (Perspektif Tokoh Ormas Islam Sumatera Utara). Jurnal Ilmu Syari'ah Dan Hukum, 46(1), 53-82.

Salendra, K. (2009). Jihad dan Terorisme Dalam Perspektif Hukum Islam. Badan Litbang dan Diklat departemen Agama RI. 
IJIK, Vol. 11 No. 2: 78-89

Terrorism and Jihad in Islamic Perspective

Doly Andhika, Ni Made Sumaryani

Shihab, M. Q. (1996). Wawasan al-Qur'an: Tafsir Maudhu'i atas Berbagai Persoalan Ummat (3rd ed.). Mizan.

Sugiyono. (2008). Metode Penelitian Kuantitatif, Kualitatif dan R\&D. Alfabeta.

Sulaiman, M. I. (2005). al-Wujuh wa al-NadzaIr fi al-Qur'an al-'Adzim.

Surpi, N. K., Sumaryani, N. M., \& Sofa, A. (2019). Counter Terrorism Against the Mindset of Women and Children Perpetrator of Terror: The Study Philosophical of Success, Time and Bravery in Overcoming Terrorism in Indonesia. In J. Mahroza, S. Aritonang, \& R. A. G. Gultom (Eds.), Proceedings 3rd Indonesia International Defense Science Seminar (pp. 117-126). Indonesia Defense University. https://doi.org/978-602-5808-48-7

Thohirin. (2021, March). Polisi Dalami Sebab ZA Penyerang Mabes Polri DO dari Kampus. CNN Indonesia.

Tim Redaksi Kamus Besar Bahasa Indonesia. (2008). Kamus Besar Bahasa Indonesia. Pusat Bahasa. 